\title{
COGNITIVE BEHAVIORAL THERAPY UNTUK MENINGKATKAN REGULASI EMOSI PADA ANAK KORBAN KONFLIK ACEH
}

\author{
Rina Mirza dan Wiwiek Sulistyaningsih \\ Universitas Sumatera Utara
}

\begin{abstract}
ABSTRAK
Anak yang mengalami masalah emosi sering sekali merasa kesulitan dalam mengontrol emosinya, hal inilah yang dialami oleh sebagian anak korban konflik Aceh. Bagi anak, hilangnya nyawa seseorang yang sangat dicintainya merupakan suatu hal yang menyakitkan. Rasa sakit yang ada dalam diri anak inilah yang kemudian menjadi pemicu ketidakstabilan emosi. Hal ini mengakibatkan anak akan mengembangkan kebencian pada kejadian ataupun pihak-pihak yang menimbulkan rasa sakit tersebut. Untuk itu, perlu dilakukan satu cara agar anak dapat mengontrol emosinya atau menyesuaikan emosi yang timbul agar tidak terjadi suatu hal yang membahayakan dikemudian hari. Cara mengontrol emosi itu disebut juga dengan regulasi emosi. Penelitian ini bertujuan untuk menguji penerapan CBT dalam meningkatkan regulasi emosi. Metode $C B T$ yang digunakan adalah cognitive restructuring methods dengan teknik pencatatan pikiran negatif dan problem solving sedangkan untuk komponen behavioral menggunakan relaksasi dengan teknik relaxation via tension relaxation. Penelitian ini menggunakan pendekatan kualitatif dengan metode singlecase design. Sesi CBT dilaksanakan sebanyak delapan sesi, enam sesi kognitif dan dua sesi behavioral. Pada sesi ini diberikan psycho education, problem solving, dan relaksasi. Subjek dalam penelitian ini adalah AG, seorang anak perempuan berusia 12 tahun. Ia menyimpan kemarahan dan mempunyai keinginan untuk balas dendam kepada tentara yang telah membunuh ayahnya saat konflik di Aceh 8 tahun silam. Hal ini sebagai pemicu munculnya ketidak stabilan emosi. Hasil yang diperoleh menunjukkan adanya peningkatan kemampuan regulasi emosi subjek penelitian. Pada awalnya, AG memiliki distorsi pikiran yang berlebihan (overgeneralization). Ia mempunyai anggapan bahwa tentara harus bertanggung jawab terhadap kehidupan keluarganya, namun setelah terapi diberikan ia memaafkan orang yang telah membunuh ayahnya dan beranggapan bahwa kematian ayahnya merupakan takdir dari Allah SWT.
\end{abstract}

Kata-kata kunci: Regulasi emosi, anak korban konflik, intervensi CBT

\section{COGNITIVE BEHAVIORAL THERAPY TO IMPROVE EMOTION REGULATION AMONG CHILDREN VICTIMS OF CONFLICT IN ACEH}

\begin{abstract}
Children who experience emotional problems often find difficulty in controlling their emotions, it is experienced by some children are victims of the conflict in Aceh. For children, who loss of a loved one's life is a painful thing. The pain is inside of the child is then triggers emotional instability. This can result in the child will develop a hatred for the events or parties who caused the pain. For that, there should be one way that children are able to control his emotions. How to control these emotions are also called emotion regulation. This study aims to test the application of CBT in improving emotion regulation. CBT methods used are cognitive restructuring methods with techniques of recording negative thoughts and problem solving while using a behavioral component to relaxation with relaxation techniques via the tension relaxation.This study used a qualitative approach with the method of single-case design. CBT sessions conducted as many as eight sessions, six sessions of cognitive and two behavioral sessions. In this session, will be give psycho education, problem solving, and relaxation. The initial subject of this study is AG, she's girl 12 yearold. She kept her anger and has the desire to take revenge on the soldiers who killed her father during the conflict in Aceh, 8 years ago. It is as a trigger emotional instability.The results showed an increase in the ability of emotion regulation research subjects. At first, the $\mathrm{AG}$ has a mind of excessive distortion (overgeneralization). She had a notion that soldiers should be responsible for the lives of her family, but after treatment she is given to forgive those who killed her father and assume her father's death is the destiny of Allah SWT.
\end{abstract}

Keywords: Emotional regulation, children victims of conflict, CBT intervention

Salah satu daerah di Indonesia yang mengalami suatu kejadian konflik yang bersifat multidimensi adalah Propinsi Nanggroe Aceh Darussalam (NAD).Suatu

*Korespondensi mengenai penelitian ini dapat dilayangkan kepada Rina Mirza melalui e-mail: rinamirza.psi@gmail.com kelompok separatis yaitu Gerakan Aceh Merdeka atau yang lebih dikenal yang sebutan GAM pernah menuntut adanya pemisahan diri dan ingin membentuk

Rekomendasi mensitasi:

Mirza, R., \& Sulistyaningsih, W. (2013). Cognitive behavioral therapy untuk meningkatkan regulasi emosi pada anak korban konflik Aceh. Psikologia, 8(2), 59-72. 
negara baru. Hal inilah yang pada akhirnya menyebabkan konflik peperangan didaerah yang kita kenal dengan istilah "Bumi Serambi Mekkah". Konflik tersebut mengakibatkan banyak wanita diperkosa, anak-anak maupun orang dewasa lainnya dibunuh (Grunady, 2007), tidak sedikit istri yang kehilangan suaminya atau anakanak menjadi yatim piatu (Kelompok Kerja Gender, 2007). Hal-hal tersebut mengakibatkan trauma yang mendalam sehingga menimbulkan masalah emosi akibat kematian orang-tua yang juga dirasakan oleh anak-anak di daerah konflik Aceh ini (Levine \& Kline, 2007).

Berkaitan dengan masalah emosi, Gohm dan Clore (dalam Safaria \& Saputra, 2009) membagi emosi dalam dua bagian, yakni: (1) Emosi positif, yakni merupakan reaksi emosi yang dapat memberi dampak menyenangkan bagi diri kita seperti ketenangan, rilek, gembira, bahagia, dan sebagainya; dan (2) emosi negatif, yakni merupakan reaksi emosi yang dapat memberi dampak tidak menyenangkan bagi diri kita seperti sedih, putus asa, marah, keinginan balas dendam, dan sebagainya. Berkaitan dengan masalah emosi yang negatif, Rusmana (2006) menyebutkan bahwa banyak anak-anak Aceh yang mengalami masalah emosi yang negatif, tidak sedikit dari anak-anak tersebut yang memendam rasa marah dan keinginan balas dendam kepada orang yang telah membunuh orang yang dicintainya. Muzakar dan Alwie (2009) menambahkan bahwa sebagian dari anakanak tersebut saat ini berada disalah satu sekolah di daerah Aceh, yaitu sekolah Dayah (pondok pesantren) Markaz AlIslah Al-Aziziyah, yang terletak di Desa Luengbata-Banda Aceh.

Dalam kamus besar Bahasa Indonesia (Talisa, 2008), balas dendam diartikan sebagai keinginan yang keras untuk membalas atau melakukan hal yang setimpal.Tindakan balas dendam terhadap sesuatu hal yang tidak rasional merupakan suatu yang tidak normal sehingga harus ada langkah untuk mengatasinya. Seorang anak yang ayahnya terbunuh, ingin sekali mencari orang yang telah membunuh ayahnya dan membalaskan dendamnya dengan melakukan hal yang sama seperti apa yang telah dialami ayahnya kala itu. Ini merupakan salah satu tindakan yang tidak rasional dan hal ini dialami oleh sebagian besar anak-anak korban konflik di Aceh.

Salah seorang psikolog Universitas Syiah Kuala Darussalam, Nur Jannah Nitura kepada ANTARA news (2006)menjelaskan bahwa anak-anak korban konflik yang berada di beberapa wilayah rawan gangguan keamanan di Provinsi Nanggroe Aceh Darussalam (NAD) perlu mendapat penanganan melalui pendekatan psikologis sebagai upaya menghapuskan rasa dendam dalam diri mereka. Jika tidak segera ditangani, maka akan melahirkan generasi pendendam. Setyawan (2007) menambahkan bahwa anak-anak yang mengalami masalah emosi negatif dapat mengakibatkan terjadinya ketegangan emosi yang semakin meningkat sehingga menyebabkan sulitnya dalam mengontrol emosi.Bagi anak sebagai anggota terlemah dalam keluarga, konflik yang terjadi hingga mengakibatkan hilangnya nyawa seseorang yang sangat dicintainya merupakan suatu hal yang menyakitkan.Rasa sakit yang ada dalam diri anak inilah yang kemudian menjadi pemicu ketidakstabilan emosi. Hal ini dapat mengakibatkan anak mengembangkan kebencian pada kejadian, seseorang ataupun pihak-pihak yang menimbulkan rasa sakit tersebut.

Untuk mengatasi ketegangan tersebut, anak perlu belajar untuk mengontrol emosinya agar ia lebih mampu berperilaku yang sesuai dan tidak terjadi suatu hal yang membahayakan di kemudian hari. Cara mengontrol emosi tersebut, disebut juga dengan regulasi emosi. Menurut Danner, Snowdon dan Friesen (dalam Atkinson \& Hilgard, 2003), seseorang yang memiliki regulasi emosi yang baik, dapat mengendalikan dan 
mengekspresikan emosi yang dirasakannya secara tepat. Martin (2003) dan Goleman (2009) menambahkan bahwa ada beberapa ciri-ciri individu yang memiliki regulasi emosi yang baik, diantaranya adalah memiliki kendali diri, hubungan interpersonal yang baik, sikap hati-hati, luwes dalam menangani perubahan dan tantangan, toleransi terhadap frustasi, pandangan yang positif, peka terhadap perasaan orang lain, melakukan introspeksi dan relaksasi, lebih sering merasakan emosi positif daripada emosi negatif, serta tidak mudah putus asa.

Rasa marah yang timbul hingga menyebabkan keinginan balas dendam merupakan suatu hal yang tidak rasional (Safaria \& Saputra, 2009). Pemikiran yang tidak rasional tersebut perlu dikoreksi dengan dilakukannya sebuah intervensi. Dalam beberapa penelitian terdahulu disebutkan bahwa intervensi Cognitive Behavioral Therapy (CBT) telah berhasil mengurangi gejala yang berkaitan dengan masalah emosi (Baucom, Sayers \& Scher, dalam Oemarjoedi, 2003; Schiraldi, 2009; \& Stallard, 2005).

Dalam CBT, terapis berupaya membantu klien untuk merubah pikiran dan pernyataan negatif serta keyakinan tidak rasional yang dialaminya. Pemikiran yang tidak rasional dapat menimbulkan masalah emosi. Dengan demikian, CBT diarahkan untuk memodifikasi fungsi berpikir, merasa dan bertindak dengan menekankan peran otak dalam menganalisa, bertanya, berbuat dan memutuskan kembali sehingga diharapkan berubah tingkah lakunya dari sesuatu yang negatif menjadi lebih positif (Cormier \& Cormier, dalam Lumongga, 2009). Disamping itu, CBT juga merupakan kombinasi antara komponen kognitif dan komponen perilaku (Martin \& Pears, 2007).

Dalam hal penelitian ini, komponen kognitif yang digunakan adalah cognitive restructuring methods, dengan teknik pencatatan pikiran negatif dan problem solving (pemecahan masalah). Hal ini dilakukan untuk mengajarkan pada anak agar ia lebih dapat mencari jalan keluar dari masalah emosi yang sedang dialaminya. Sementara itu, untuk komponen behavioral yang digunakan adalah relaksasi dengan teknik relaxation via tension relaxation. Dalam hal ini, anak diminta untuk menegangkan masingmasing ototnya dan melemaskan kembali masing-masing otot tersebut, kemudian anak diminta untuk merasakan dan menikmati perbedaan antara ketika otot tegang dan otot lemas. Pada teknik ini anak dilatih untuk melemaskan otot-otot tegang dengan cepat, seolah-olah mengeluarkan ketegangan dari badan sehingga individu akan merasa rileks dan dapat menurunkan aktivitas berpikir negatif serta mengalihkannya kepada halhal yang lebih positif.Berdasarkan uraian di atas maka diformulasikanlah sebuah judul yakni "Cognitive Behavioral Therapy Untuk Meningkatkan Regulasi Emosi Pada Anak Korban Konflik Aceh".

Penelitian ini menggunakan data tunggal, dimana yang menjadi subjek penelitiannya adalah seorang anak perempuan yang berinisial AG berusia 12 tahun dan saat ini duduk di kelas I SMP yang didiagnosa mengalami PTSD.Ia adalah salah satu anak yang ayahnya terbunuh ketika konflik di Aceh Tamiang beberapa tahun silam. Saat ini ia mempunyai keinginan yang tidak rasional, ia sangat ingin mencari pelaku atau kelompok tertentu (tentara) yang telah membunuh ayahnya serta membalaskan dendamnya dengan melakukan perbuatan yang setimpal seperti apa yang dialami ayahnya ketika itu.

Dengan pemberian CBT ini diharapkan AG lebih mampu mengontrol emosinya (regulasi emosi) sehingga ia lebih dapat mengatasi masalah emosi yang dirasakannya yakni memendam kemarahan dan menyimpan keinginan balas dendam terhadap orang yang telah membunuh ayahnya. 


\section{METODE}

\section{Pendekatan}

Penelitian ini menggunakan pendekatan kualitatif dengan metode single-case design, artinya bahwa dalam penelitian ini hanya menggunakan satu orang subjek (kasus tunggal) secara mendalam untuk diberikan perlakuan yang bertujuan untuk mengevaluasi bagaimana efektivitasnya dalam penerapan suatu program tertentu. Penggunaan metode kualitatif memungkinkan peneliti untuk mengetahui lebih jelas bagaimana proses dan hasil penerapan metode latihan relaksasi dan cognitive restructuring methods melalui cara deskripsi dalam bentuk kata-kata, bahasa, perilaku pada suatu konteks khusus yang alamiah dan memanfaatkan berbagai metode pengambilan data.

\section{Subjek Penelitian}

Subjek dalam penelitian ini adalah seorang anak perempuan yang berinisial AG dan saat ini berusia 12 tahun. AG adalah anak kedua dari empat orang bersaudara.Ia merupakan salah satu anak yang ayahnya terbunuh pada masa pemberontakan Gerakan Aceh Merdeka 8 tahun yang lalu. Ketika itu ia berumur 4 tahun, sehingga ia masih dapat mengingat kejadian kontak senjata di daerah tempat tinggalnya. Kematian ayah secara tragis dan cerita yang ia peroleh dari orang sekitarnya mengenai peristiwa yang menimpa ayahnya membuatnya sangat terpukul. Ia sangat marah dan membenci serta sangat ingin mencari orang yang telah membunuh ayahnya kemudian membalaskan dendamnya seperti apa yang telah dilakukan tentara-tentara tersebut kepada ayahnya.

Kejadian tersebut memicu terjadinya ketidakstabilan emosi, selain itu apa yang dirasakan AG merupakan salah satu bagian dari emosi negatif dan harus dilakukan suatu cara agar emosi negatif itu tidak membebani jiwanya. Untuk itu perlu satu cara agar ia dapat mengontrol emosinya. Intervensi ini bertujuan agar AG dapat mengontrol emosinya sehingga ia lebih mampu mengatasi reaksi emosi yang dirasakannya.

Rasa marah, benci dan keinginan balas dendam yang dipendamnya, terbawa hingga ke alam bawah sadarnya.Ia sering mengigau memanggil ayahnya dan memaki orang yang telah membunuh ayahnya.Ia juga selalu menghindari segala stimulus yang berkaitan dengan peristiwa yang menimpa ayahnya seperti siaran televisi tentang pembunuhan dan peperangan hingga menghindari pembicaraan yang berkaitan dengan kejadian yang menimpa ayahnya. Termasuk peristiwa yang mengingatkannya pada ayahnya, misalnya orang yang bertamu ke rumahnya, mengingatkannya pada kejadian pembunuhan ayahnya karena salah seorang tetangga juga yang memberitahu kabar tersebut.

Ia menghindari segala stimulus yang berkaitan dengan peristiwa kematian ayahnya, termasuk menolak untuk membicarakan tentang kejadian itu. Ia merasa nyaman dengan diam, tanpa membicarakan tentang kejadian itu. Hal ini juga semakin diperkuat dengan ciri kepribadian AG yang cenderung tertutup, ia lebih senang memendam perasaannya sendiri.

Berdasarkan hasil pemeriksaan psikologis diketahui bahwa AG memiliki kapasitas kecerdasan yang berfungsi pada taraf rata-rata bawah (Full Scale $I Q=91$, menurut skala Wechsler). Hal ini menunjukkan bahwa ia dapat mengikuti proses belajar di sekolahnya, namun membutuhkan usaha yang keras. Untuk mempermudah AG dalam belajar maka ia harus melibatkan kemampuan visual dan auditorinya. Dalam belajar, ia tidak hanya mengandalkan kemampuan apa yang didengarnya dari guru namun ia harus melihat, mencatat hal-hal yang dianggapnya penting. Hal ini menunjukkan 
Tabel 1 Ringkasan intepretasi hasil terapi

\begin{tabular}{|c|c|c|c|}
\hline Sesi & $\begin{array}{l}\text { Proses } \\
\text { terapi }\end{array}$ & Tujuan terapi & Hasil terapi \\
\hline 1 & $\begin{array}{l}\text { Formulation } \\
\text { dan psycho } \\
\text { edu cation }\end{array}$ & $\begin{array}{l}\text { - Mengenali kemampuan diri. } \\
\text { - Memberi kesadaran memiliki } \\
\text { masalah emosi dan adanya } \\
\text { keinginan untuk mengontrol } \\
\text { emosinya. } \\
\text { - Memberi pemahaman proses } \\
\text { terapi. }\end{array}$ & $\begin{array}{l}\text { AG dapat mengenali kemampuan yang dimilikinya } \\
\text { dan menyadari menyimpan emosi negatif yakni } \\
\text { keinginan balas dendam terhadap orang yang telah } \\
\text { membunuh ayahnya dan ingin belajar mengendalikan } \\
\text { emosi negatif yang dirasakannya. }\end{array}$ \\
\hline 2 & $\begin{array}{l}\text { Formulation } \\
\text { dan psycho } \\
\text { edu cation }\end{array}$ & $\begin{array}{l}\text { - Memberi pemahaman } \\
\text { hubungan pikiran, perasaan } \\
\text { dan tingkah laku. } \\
\text { - Merumuskan masalah. } \\
\text { - Memberinya tugas rumah. }\end{array}$ & $\begin{array}{l}\text { AG memahami bahwa tingkah laku yang muncul } \\
\text { berawal dari pemikiran dan perasaannya. Namun, ia } \\
\text { belum dapat menentukan apa yang dipikirkannya } \\
\text { merupakan hal yang rasional atau tidak rasional. la } \\
\text { sadar bahwa tingkah laku tersebut muncul, karena } \\
\text { kemarahan yang dipendamnya selama ini. }\end{array}$ \\
\hline 3 & $\begin{array}{l}\text { Thought } \\
\text { monitoring }\end{array}$ & $\begin{array}{l}\text { - Identifikasi kognisi umum dan } \\
\text { pola pikir AG. } \\
\text { - Menjelaskan hubungan } \\
\text { pikiran, perasaan dan } \\
\text { perilaku. }\end{array}$ & $\begin{array}{l}\text { AG mengetahui apa dan bagaimana cara memberi } \\
\text { makna terhadap pikiran negatif yang dirasakannya. la } \\
\text { menyadari tidak selamanya pikiran yang pertama } \\
\text { sekali muncul merupakan hal yang dapat terjadi, } \\
\text { karena membutuhkan pemikiran lagi dalam } \\
\text { memaknai pemikiran tersebut agar lebih masuk akal. } \\
\text { Selain itu, ada distorsi pikiran yang berlebihan } \\
\text { (overgeneralisasi). Baginya, seseorang harus } \\
\text { bertanggung jawab atas kehidupan mereka setelah } \\
\text { kematian ayahnya. la juga sangat membenci segala } \\
\text { hal yang berkaitan dengan tentara serta atributnya. }\end{array}$ \\
\hline 4 & $\begin{array}{l}\text { Problem } \\
\text { solving }\end{array}$ & $\begin{array}{l}\text { - Mengajarkan cara mencari } \\
\text { solusi atas masalah emosi } \\
\text { yang dirasakannya. } \\
\text { - Evaluasi sesi terapi kognitif }\end{array}$ & $\begin{array}{l}\text { AG dapat mencari solusi atas masalah emosi yang } \\
\text { dirasakannya. Walau belum begitu berhasil, namun } \\
\text { AG masih dapat mengerjakan tugas yang diberikan } \\
\text { kepadanya dengan bantuan dan motivasi. }\end{array}$ \\
\hline 5 & $\begin{array}{l}\text { Affective } \\
\text { manage } \\
\text { Ment }\end{array}$ & $\begin{array}{l}\text { - Memberi alternatif cara } \\
\text { mengontrol emosi. } \\
\text { - Membuat AG lebih nyaman } \\
\text { melalui relaksasi }\end{array}$ & $\begin{array}{l}\text { AG belum menaruh kepercayaan secara penuh } \\
\text { terhadap proses terapi behavioral yang dijalaninya. } \\
\text { Namun ia dapat mengikuti semua instruksi yang } \\
\text { diberikan. }\end{array}$ \\
\hline 6 & $\begin{array}{l}\text { Problem } \\
\text { solving }\end{array}$ & $\begin{array}{l}\text { - Mencari solusi terhadap } \\
\text { masalah emosi yang } \\
\text { dirasakannya. } \\
\text { - Menganalisa sesi terapi } \\
\text { kognitif dan perilaku }\end{array}$ & $\begin{array}{l}\text { AG dapat menganalisa masalah yang sedang } \\
\text { dihadapinya yakni keinginannya untuk balas dendam } \\
\text { terhadap tentara yang telah membunuh ayahnya. } \\
\text { Namun rasanya mustahil untuk melakukan hal itu } \\
\text { karena ia tidak tahu persis siapa orang yang telah } \\
\text { membunuh ayahnya. Selain itu, ia juga tidak tahu } \\
\text { apakah orang tersebut masih hidup atau sudah } \\
\text { meninggal sebab kejadiannya telah berlangsung } 8 \\
\text { tahun yang lalu. Walau masih memendam keinginan } \\
\text { itu, ia berharap Allah SWT akan membalaskan } \\
\text { dendamnya. }\end{array}$ \\
\hline 7 & $\begin{array}{l}\text { Affective } \\
\text { manage } \\
\text { Ment }\end{array}$ & $\begin{array}{l}\text { - Membuat AG lebih nyaman } \\
\text { - Melatih melemaskan otot-otot } \\
\text { tegang dengan cepat, } \\
\text { seolah-olah mengeluarkan } \\
\text { ketegangan dari badan. }\end{array}$ & $\begin{array}{l}\text { AG telah menerapkan teknik yang telah diajarkan } \\
\text { pada sesi terapi sebelumnya. la dapat secara } \\
\text { otomatis mengontrol emosi yang dirasakannya. }\end{array}$ \\
\hline & $\begin{array}{l}\text { Psycho } \\
\text { Education }\end{array}$ & $\begin{array}{l}\text { - Memberi pemahaman } \\
\text { hubungan pikiran, perasaan } \\
\text { dan tingkah laku. } \\
\text { - Merumuskan masalah emosi } \\
\text { yang dirasakannya. } \\
\text { - Evaluasi hasil terapi secara } \\
\text { keseluruhan. }\end{array}$ & $\begin{array}{l}\text { Sesi ini berjalan sesuai dengan tujuan, meskipun ia } \\
\text { belum dapat melupakan kejadian yang menimpa } \\
\text { ayahnya namun ia berusaha untuk terus belajar } \\
\text { memaafkan orang yang telah membunuh ayahnya. la } \\
\text { sadari tidak dapat melakukan apapun kecuali berdoa } \\
\text { semoga orang yang telah membunuh ayahnya } \\
\text { mendapatkan balasan yang setimpal atas perbuatan } \\
\text { yang telah dilakukannya. }\end{array}$ \\
\hline
\end{tabular}


bahwa ia dapat mengikuti proses belajar di sekolahnya, namun membutuhkan usaha yang keras. Untuk mempermudah $A G$ dalam belajar maka ia harus melibatkan kemampuan visual dan auditorinya. Dalam belajar, ia tidak hanya mengandalkan kemampuan apa yang didengarnya dari guru namun ia harus melihat, mencatat halhal yang dianggapnya penting. Hal ini memudahkannya dalam mengikuti proses belajar.

\section{Lokasi Penelitian}

Penelitian ini merupakan penelitian lapangan dan lokasi penelitian ditentukan berdasarkan kesepakatan antara peneliti dengan subjek penelitian.Penelitian ini dilaksanakan di ruang tamu kediaman ibu AL yang merupakan tetangga dari AG. Rumah ibu AL dipilih karena dianggap lebih nyaman dan tenang sehingga dapat membantu berjalannya proses terapi.

\section{HASIL}

Sesi CBTdilaksanakan sebanyak delapan kali, enam sesi kognitif dan dua sesi perilaku. Pelaksanaan terapi ini dilakukan pada tanggal 1, 2, 4 dan 5 Juli 2011. Tanggal 3 Juli 2011 merupakan hari Minggu, sehingga terapi ditiadakan atas kesepakatan bersama, namun tugas harian tetap dikerjakan dan analisa hasil tugas harian tersebut dilakukan pada hari berikutnya. Ringkasan intepretasi hasil terapi dapat dilihat pada Tabel 1.

\section{Evaluasi hasil terapi}

\section{Evaluasi I}

Evaluasi I dilakukan untuk terapi sesi 1, 2, 3 dan 4, yakni terapi kognitif. Dari keempat sesi terapi terlihat AG membutuhkan lebih banyak dorongan dan keyakinan bahwa ia dapat mengerjakan setiap tugas yang diberikan kepadanya. Ia tidak banyak menjawab saat ditanyakan namun ia menjawabnya dengan tulisan yang dituangkannya dalam lembar kerja. Pada awalnya, sesi terapi hanya menggunakan rekaman melalui telepon genggam, namun karena sulitnya AG mengeluarkan kata sehingga diputuskan untuk memakai rekaman video agar situasi yang terjadi selama terapi berlangsung dapattergambarkan secara jelas. Sulitnya AG menjawab hanya pada hal-hal yang berkaitan dengan masalah ayahnya, tentara dan pembunuhan ayahnya. Sementara jika ditanyakan hal lain, ia mau dan dapat menceritakan serta menjawab semua pertanyaan yang diajukan kepadanya. Dalam hal ini, peneliti mencoba menanyakan secara bergantian hal-hal yang hendak ditanyakan.

\section{Evaluasi II}

Evaluasi ini dilakukan untuk terapi sesi 5 dan 6 yakni terapi behavioral dan kognitif. Berdasarkan evaluasi pertama diketahui bahwa AG membutuhkan dorongan dalam mengerjakan tugas yang diberikan kepadanya sehingga pada sesi terapi berikutnya hal ini dilakukan dan semua berjalan dengan baik. Sementara itu untuk sesi terapi behavioral yakni teknik relaksasi, AG sulit untuk menutup matanya. Awalnya peneliti membebaskan AG untuk memilih menutup atau tidak menutup matanya. Ketika itu, ia lebih memilih tidak menutup mata, dan selama relaksasi berlangsung AG terlihat mengamati ruangan sekitar. Untuk itu, terapis memintanya untuk menutup mata agar ia lebih konsentrasi. Butuh waktu lama untuk meyakinkan AG agar ia mau menutup matanya dan mengikuti semua instruksi yang diberikan. Dalam hal ini peneliti memberi penekanan dan pengulangan untuk hal-hal yang penting serta yang harus dilakukannya sehingga ia dapat melakukannya.

\section{Evaluasi III}

Evaluasi ini dilakukan di akhir sesi, pada saat mengakhiri sesi terapi. Evaluasi ini meliputi semua sesi dalam proses terapi ini baik terapi kognitif maupun terapi behavioral. Evaluasi ketiga ini bertujuan untuk mengevaluasi jalannya sesi terapi secara keseluruhan. Dari semua evaluasi 
Tabel 2 Kemampuan regulasi emosi AG sebelum dan sesudah terapi

\begin{tabular}{llcc}
\hline & Indikator kemampuan regulasi emosi & \multicolumn{2}{c}{ Skor hasil } \\
\cline { 3 - 4 } & Sebelum & Sesudah \\
\hline 1. & Kendali diri & 0 & 2 \\
2. & Hubungan interpersonal dengan orang lain. & 0 & 0 \\
3. & Sikap hati-hati. & 1 & 2 \\
4. & Adaptabilitas & 0 & 0 \\
5. & Toleransi yang lebih tinggi terhadap frustasi. & 1 & 2 \\
6. & Pandangan yang positif terhadap diri dan lingkungannya. & 0 & 2 \\
7. & Peka terhadap perasaan orang lain. & 1 & 1 \\
8. & Melakukan introspeksi dan relaksasi & 0 & 1 \\
9. & Lebih sering merasakan emosi positif daripada emosi negatif. & 0 & 2 \\
10. & Tidak mudah putus asa dalam menghadapi masalah. & 1 & 1 \\
& Skor total & $\mathbf{4}$ & $\mathbf{1 3}^{\star}$ \\
\hline
\end{tabular}

${ }^{*}$ Skor angka 4 (sebelum terapi) dan 13 (sesudah terapi), diartikan bahwa adanya perubahan dalam hal kemampuan AG dalam meregulasi emosinya. Ada beberapa indikator yang sudah dibuat untuk melihat kemampuannya, seperti yang sudah dicantumkan pada tabel diatas. Semakin tinggi nilai yang ditunjukkannya, maka menunjukkan semakin meningkat pula kemampuan regulasi emosinya.

yang telah dilakukan, cukup membantu dalam melancarkan jalannya setiap sesi yang dilakukan.

\section{Perbandingan data sebelum dan sesudah terapi}

\section{Kemampuan regulasi emosi sebelum dan sesudah intervensi CBT}

Berdasarkan hasil wawancara, deskripsi mengenai kemampuan regulasi AG sebelum dan sesudah intervensi CBT dapat dilihat pada Tabel 2. Pada indikator yang pertama yakni kemampuan kendali diri mengalami peningkatan. Dalam hal ini AG sudah mulai dapat mengendalikan perasaan emosi yang dirasakannya. Sebelum terapi diberikan, jika mengingat kejadian yang telah menimpa ayahnya, ia merasa ingin sekali berlari keluar rumah dan mencoba mencari orang yang telah membunuh ayahnya walau hasilnya tidak menemukan orang yang dicari. Setelah terapi, ia hanya diam dirumah dan mencari kesibukan agar tidak teringat dengan hal yang sangat menyakitkan itu sembari mencoba untuk memaafkan orang yang telah membunuh ayahnya.

Untuk indikator kedua, yakni kemampuan hubungan interpersonal dengan orang lain tidak mengalami perubahan. Meskipun terapi telah diberikan, namun kebencian yang dirasakannya terhadap tentara yang telah membunuh ayahnya masih tetap membekas dalam sulit bagi AG memaafkan orang yang telah membunuh ayahnya. Walau demikian, ia menyatakan bahwa ia mau belajar untuk memaafkan orang yang telah membunuh ayahnya. Untuk indikator ketiga yakni sikap hatihati juga mengalami perubahan. Sebelum terapi, ia akan melakukan sesuatu tanpa dipikirkan terlebih dahulu dampak yang menyertainya. Namun setelah terapi, ia akan memikirkan terlebih dahulu dengan matang apa yang akan dilakukannya agar hasilnya lebih baik.

Indikator keempat yakni adaptabilitas tidak mengalami perubahan (menetap). Baik sebelum terapi maupun setelah terapi diberikan, AG mengalami kesulitan dalam menghadapi setiap perubahan yang terjadi dalam hidupnya. Walau kenyataannya, ia harus menghadapi juga masalah-masalah tersebut. Indikator kelima yakni toleransi terhadap frustasi juga mengalami perubahan. Sebelum terapi, ia sulit mengatasi kemarahannya terutama yang berkenaan dengan kematian ayahnya akibat dibunuh oleh tentara hingga munculnya keinginan balas dendam. Namun setelah terapi diberikan, ia lebih dapat mengatasi kemarahannya dengan berpikir bahwa kemarahan bukanlah jalan keluar dari masalah yang sedang dirasakannya.

Indikator keenam yakni pandangan yang positif terhadap diri dan lingkungan 
mengalami peningkatan. Sebelum terapi, AG merasa bahwa seseorang harus bertanggung jawab atas kematian ayahnya karena jika tidak dibunuh ayahnya pasti masih hidup dan berada disampingnya saat ini. Namun setelah terapi, terjadi peningkatan bahwa seseorang tidak harus bertanggung jawab atas kematian ayahnya karena AG yakin bahwa ayahnya meninggal dunia karena sudah takdir dari Allah SWT. Indikator ketujuh yakni peka terhadap perasaan orang lain tidak mengalami perubahan (menetap). Baik sebelum maupun sesudah terapi diberikan ia mempunyai anggapan bahwa seseorang berbuat sesuatu karena ada penyebabnya, namun dalam bersikap ia tidak akan memperdulikan anggapan orang lain karena ia berbuat sesuai dengan apa yang diinginkannya.

Indikator kedelapan yakni

kemampuan dalam introspeksi dan melakukan relaksasi mengalami perubahan. Setelah terapi, ia akan merasa nyaman dengan duduk dan memejamkan mata saat teringat akan kematian ayahnya. Namun hal ini tidak terjadi sebelum terapi karena dengan duduk berdiam diri maupun memejamkan mata bukanlah cara yang tepat untuk membuatnya nyaman karena ia tetap teringat akan kematian ayahnya yang sangat tragis. Akan tetapi ia masih menyimpan suatu pemikiran bahwa tentara harus bertanggung jawab atas kehidupan mereka sekeluarga karena tentara telah membunuh ayah mereka sebagai orang yang memenuhi kebutuhan hidup mereka sehari-hari, walau terapi sudah diberikan.

Indikator kesembilan yakni lebih sering merasakan emosi positif dari pada emosi negatif juga mengalami perubahan. Dalam menjalani hidup ini, ia tidak merasa senang dan sering memendam kemarahan. Setelah terapi, ia tidak lagi memendam kemarahan dan merasa lebih senang dalam menjalani hidup ini. Indikator yang terakhir yakni yang kesembilan berkenaan dengan tidak mudah putus asa dalam mengahadapi masalah tidak mengalami perubahan (menetap). Ia yakin bahwa jika ia berusaha maka ia akan menemukan jalan keluar dari masalah yang sedang dihadapinya dan ia menyerahkan segalanya pada Allah sebagai sosok yang paling mengerti akan baik-buruk segala sesuatu yang harus dilakukannya.

Secara keseluruhan hasil yang diperoleh menunjukkan adanya peningkatan kemampuan regulasi emosi subjek penelitian. Setelah terapi diberikan, kemampuan kendali diri, sikap hati-hati, toleransi terhadap frustasi, memiliki pandangan yang positif terhadap diri sendiri dan lingkungan, lebih dapat melakukan introspeksi diri dan relaksasi serta lebih sering merasakan emosi yang positif dari pada emosi negatif mengalami peningkatan. Sementara itu, kemampuannya dalam menjalin hubungan interpersonal dengan orang lain, adaptabilitas, kepekaan terhadap orang lain dan tidak mudah putus asa tidak mengalami perubahan (menetap). Kesimpulan mengenai perubahan kemampuan regulasi emosi $A G$ sebelum dan sesudah terapi CBT dapat dilihat pada Tabel 3.

Sebagaimana telah dibahas sebelumnya bahwa pelaksanaan intervensi CBT ini dilakukan sebanyak 8 sesi selama 4 hari, dimana 1 hari dilakukan 2 sesi. Terapi ini dianggap selesai walau perilaku dan pemikiran yang diharapkan belum terbentuk secara keseluruhan dan konsisten karena ia belum dapat melupakan orang yang telah membunuh ayahnya. Namun kemampuan AG dalam hal regulasi emosi sudah menunjukkan peningkatan dan ia juga berjanji akan berupaya terus untuk belajar memaafkan orang yang telah membunuh ayahnya.

Untuk memastikan apakah terapi yang dilakukan selama 8 sesi tersebut mempunyai manfaat dan dapat meningkatkan kemampuan AG dalam hal regulasi emosi, pada tanggal 22 Juli 2011 tepatnya 17 hari setelah sesi terapi selesai maka peneliti kembali menanyakan mengenai kemampuan $\mathrm{AG}$ dalam hal regulasi emosinya. Hal ini dilakukan untuk 
Tabel 3 Perubahan kemampuan regulasi emosi AG sebelum dan sesudah intervensi CBT

\begin{tabular}{lll}
\hline Kemampuan yang meningkat & Kemampuan yang menetap \\
\hline - Kendali diri & $\bullet \quad$ Hubungan interpersonal dengan orang \\
- Sikap hati-hati & lain & Adaptabilitas \\
- Toleransi terhadap frustasi & $\bullet \quad$ Peka terhadap perasaan orang lain \\
- Memiliki pandangan yang positif terhadap diri sendiri & $\bullet \quad$ Tidak mudah putus asa dalam \\
- Man lingkungan & & menghadapi masalah. \\
- $\quad$ Lelakukan introspeksi diri dan relaksasi & \\
\hline
\end{tabular}

Tabel 4 Kemampuan regulasi emosi subjek sesudah intervensi CBT dan follow-up

\begin{tabular}{llr}
\hline & \multicolumn{1}{c}{ Indikator kemampuan regulasi emosi } & Skor hasil \\
\cline { 2 - 3 } & Sesudah & Follow-up \\
\hline 1. Memiliki kendali diri & 2 & 2 \\
2. Memiliki hubungan interpersonal yang baik dengan orang lain. & 0 & 2 \\
3. Memiliki sikap hati-hati. & 2 & 2 \\
4. Luwes dalam menangani perubahan dan tantangan. & 0 & 2 \\
5. Toleransi yang lebih tinggi terhadap frustasi. & 2 & 2 \\
6. Memiliki pandangan yang positif terhadap diri dan lingkungannya. & 1 & 1 \\
7. Lebih peka terhadap perasaan orang lain. & 1 & 1 \\
8. Melakukan introspeksi dan relaksasi & 2 & 1 \\
9. Lebih sering merasakan emosi positif daripada emosi negatif. & 1 \\
10. Tidak mudah putus asa dalam menghadapi masalah. & $\mathbf{1 3}$ \\
Skor total & $\mathbf{1 5}$ \\
\hline * Skor sesudah terapi menunjukkan angka 13 dan setelah masa follow up, AG diberikan tes yang sama dan \\
hasilnya menunjukkan adanya peningkatan dalam hal kemampuan regulasi emosinya yakni meningkat \\
menjadi 15.
\end{tabular}

Tabel 5 Perubahan kemampuan regulasi emosi AG sesudah intervensi dan follow-up

\begin{tabular}{ll}
\hline Kemampuan yang menetap & Kemampuan yang meningkat \\
\hline - Kendali diri & $\bullet \begin{array}{l}\text { Hubungan interpersonal dengan orang } \\
\text { - Sikap hati-hati }\end{array}$ \\
- Adaptabilitas & \\
- Toleransi terhadap frustasi & \\
- Memiliki pandangan yang positif terhadap diri sendiri & \\
- Peka terhadap perasaan orang lain \\
- Melakukan introspeksi diri dan relaksasi \\
- Lebih sering merasakan emosi yang positif dari pada \\
- Tidak mudah putus asa dalam menghadapi masalah \\
\hline
\end{tabular}

melihat apakah terapi yang diberikan dapat bertahan, meningkat atau semakin menurun dengan berjalannya waktu.Berikut ini merupakan gambaran kemampuan regulasi emosi subjek sesudah terapi CBT dengan follow-up. Seperti tertera pada Tabel 4.

Dapat dikatakan bahwa secara keseluruhan kemampuan regulasi emosi AG setelah dilakukan follow-up dapat bertahan. Bahkan semakin meningkat karena ada satu kemampuan yang mengalami perubahan yakni kemampuan- nya dalam melakukan hubungan interpersonal dengan orang lain. Pada awalnya, ia merasa kesulitan untuk memaafkan orang yang telah membunuh ayahnya. Namun seiring berjalannya waktu, ia semakin dapat memaafkan orang yang telah membunuh ayahnya. Berikut ini merupakan kesimpulan dari perubahan dari kemampuan regulasi emosi subjek sesudah terapi CBT diberikan dan sesaat setelah terapi (follow-up). 
Tabel 6 Perbandingan cara pandang AG sebelum dan sesudah intervensi CBT

\begin{tabular}{|c|c|c|c|c|c|c|}
\hline \multirow{2}{*}{ Situasi } & \multicolumn{3}{|c|}{ Sebelum terapi } & \multicolumn{3}{|c|}{ Sesudah terapi } \\
\hline & Pikiran & Perasaan & Perilaku & Pikiran & Perasaan & Perilaku \\
\hline $\begin{array}{l}\text { Kamu sedang menyaksikan } \\
\text { siaran TV, tiba-tiba } \\
\text { abangmu mengganti siaran } \\
\text { tersebut dengan berita } \\
\text { peperangan yang terjadi di } \\
\text { daerah timur tengah. }\end{array}$ & Marah & $\begin{array}{l}\text { Marah sama } \\
\text { abang }\end{array}$ & $\begin{array}{l}\text { Menukar } \\
\text { nya } \\
\text { kembali }\end{array}$ & $\begin{array}{l}\text { Tidak } \\
\text { setuju }\end{array}$ & Marah & $\begin{array}{l}\text { Menukar } \\
\text { kembali }\end{array}$ \\
\hline $\begin{array}{l}\text { Kamu terpilih menjadi } \\
\text { anggota pramuka dan } \\
\text { harus mengikuti latihan } \\
\text { baris berbaris yang dilatih } \\
\text { langsung oleh tentara. }\end{array}$ & $\begin{array}{l}\text { Tidak } \\
\text { setuju }\end{array}$ & $\begin{array}{l}\text { Tidak setuju } \\
\text { karena } \\
\text { tentara yang } \\
\text { melatih }\end{array}$ & $\begin{array}{l}\text { Tidak mau } \\
\text { ikuti apa } \\
\text { yang } \\
\text { dikatakan } \\
\text { tentara tsb. }\end{array}$ & Setuju & $\begin{array}{l}\text { Biasa } \\
\text { saja }\end{array}$ & $\begin{array}{l}\text { Mengikutinya } \\
\text { saja }\end{array}$ \\
\hline $\begin{array}{l}\text { Ketika bagi raport kemarin, } \\
\text { temanmu ditemani ayahnya } \\
\text { untuk mengambilkan } \\
\text { raportnya. }\end{array}$ & $\begin{array}{l}\text { Biasa } \\
\text { saja }\end{array}$ & $\begin{array}{l}\text { Tidak } \\
\text { merasa apa- } \\
\text { apa }\end{array}$ & $\begin{array}{l}\text { Biasa saja } \\
\text { sama } \\
\text { teman itu }\end{array}$ & Setuju & $\begin{array}{l}\text { Biasa } \\
\text { saja }\end{array}$ & Biasa saja \\
\hline $\begin{array}{l}\text { Abangmu bercita-cita ingin } \\
\text { menjadi tentara. }\end{array}$ & Setuju & $\begin{array}{l}\text { Senang } \\
\text { karena akan } \\
\text { bisa balas } \\
\text { dendam } \\
\end{array}$ & $\begin{array}{l}\text { Akan terus } \\
\text { mendukung } \\
\text { abang }\end{array}$ & $\begin{array}{l}\text { Tidak } \\
\text { setuju }\end{array}$ & $\begin{array}{l}\text { Biasa } \\
\text { saja }\end{array}$ & $\begin{array}{l}\text { Mana } \\
\text { mungkin, } \\
\text { karena abang } \\
\text { tidak sekolah }\end{array}$ \\
\hline
\end{tabular}

Tabel 7 Perbandingan analisa fungsional sebelum dan sesudah intervensi CBT

\begin{tabular}{|c|c|c|c|c|c|c|c|c|}
\hline \multirow{2}{*}{$\begin{array}{l}\text { Target } \\
\text { perilaku }\end{array}$} & \multicolumn{4}{|c|}{ Analisa fungsional sebelum terapi } & \multicolumn{4}{|c|}{ Analisa fungsional sesudah terapi } \\
\hline & $\mathbf{S}$ & 0 & $\mathbf{R}$ & C & $\mathbf{S}$ & 0 & $\mathbf{R}$ & $\mathbf{C}$ \\
\hline $\begin{array}{l}\text { Mening } \\
\text { katkan } \\
\text { kemam } \\
\text { puan } \\
\text { regulasi } \\
\text { emosi }\end{array}$ & $\begin{array}{l}\text { Melihat } \\
\text { tentara } \\
\text { atau } \\
\text { atribut } \\
\text { tentara } \\
\text { menging- } \\
\text { atkan AG } \\
\text { pada } \\
\text { peristiwa } \\
\text { kematian } \\
\text { ayahnya. }\end{array}$ & $\begin{array}{l}\text { Cognitif:Or } \\
\text { ang yang } \\
\text { membu- } \\
\text { nuh ayah } \\
\text { harus } \\
\text { bertang- } \\
\text { gung jawab } \\
\text { terhadap } \\
\text { kehidup } \\
\text { annya. } \\
\text { Emosi- } \\
\text { onal:Muncu } \\
\text { Imarah, } \\
\text { kebencian, } \\
\text { permusuh- } \\
\text { an dan } \\
\text { menyim pan } \\
\text { keinginan } \\
\text { balas } \\
\text { dendam. }\end{array}$ & $\begin{array}{l}\text { (1) Meng- } \\
\text { hindari } \\
\text { segala hal } \\
\text { yang dapat } \\
\text { membangkit } \\
\text { kan reaksi } \\
\text { emosi. } \\
\text { (2) Men } \\
\text { cari orang } \\
\text { yang telah } \\
\text { membunuh } \\
\text { ayah untuk } \\
\text { balas } \\
\text { denda. }\end{array}$ & $\begin{array}{l}\text { Positif: } \\
\text { Dukung- } \\
\text { an dari } \\
\text { keluarga } \\
\text { untuk } \\
\text { mewujudkan } \\
\text { keingin- } \\
\text { annya } \\
\text { tersebut. } \\
\text { Negatif: } \\
\text { terus } \\
\text { menerus } \\
\text { menyim pan } \\
\text { emosi } \\
\text { hingga } \\
\text { sangat } \\
\text { memben ci } \\
\text { tentara. }\end{array}$ & $\begin{array}{l}\text { Melihat } \\
\text { tentara } \\
\text { atau } \\
\text { atribut } \\
\text { tentara } \\
\text { meng- } \\
\text { ingatkan } \\
\text { AG pada } \\
\text { peristi- } \\
\text { wa } \\
\text { kemati- } \\
\text { an orang } \\
\text { (ayah) } \\
\text { yang } \\
\text { disayangi } \\
\text {-nya.. }\end{array}$ & $\begin{array}{l}\text { Cognitif: } \\
\text { Kematian } \\
\text { ayah } \\
\text { sudah } \\
\text { menjadi } \\
\text { takdir dari } \\
\text { Allah } \\
\text { SWT. } \\
\text { Emosi } \\
\text { onal: } \\
\text { Memaaf- } \\
\text { kan orang } \\
\text { yang telah } \\
\text { mem- } \\
\text { bunuh } \\
\text { ayah. }\end{array}$ & $\begin{array}{l}\text { Selalu } \\
\text { berdoa } \\
\text { semoga } \\
\text { Allah } \\
\text { SWT } \\
\text { mem- } \\
\text { balas- } \\
\text { nya } \\
\text { dengan } \\
\text { setim- } \\
\text { pal. }\end{array}$ & $\begin{array}{l}\text { Positif:M } \\
\text { erasa } \\
\text { lebih } \\
\text { nyaman } \\
\text { dan dapat } \\
\text { mengon- } \\
\text { trol emosi } \\
\text { serta } \\
\text { menga- } \\
\text { jarkan } \\
\text { nya } \\
\text { kepada } \\
\text { saudara } \\
\text { nya. } \\
\text { Negatif: } \\
\text { belum } \\
\text { sepe- } \\
\text { nuhnya } \\
\text { bisa } \\
\text { menghi- } \\
\text { langkan } \\
\text { rasa } \\
\text { marah. }\end{array}$ \\
\hline \multicolumn{9}{|c|}{$\begin{array}{l}\text { Keterangan: S (eliciting stimulus): peristiwa yang terjadi sebelum individu menunjukkan perilaku tertentu/ } \\
\text { masalah emosi. O (organism): individu dengan aspek kognisi (C) dan emosi (E) di dalamnya. Munculnya } \\
\text { masalah emosi yang harus segera ditangani. R (responses): apa yang dilakukan oleh individu atau organism, } \\
\text { sering juga disebut dengan perilaku (behavior), baik perilaku yang tampak (overt behavior) ataupun perilaku } \\
\text { yang tidak tampak (covert behavior). C (consequences): peristiwa yang terjadi setelah atau sebagai suatu } \\
\text { hasil dari perilaku. Consequences termasuk apa yang terjadi secara langsung pada individu, orang lain, dan } \\
\text { lingkungan } \quad \text { fisik sebagai } \quad \text { suatu } \quad \text { hasil dari } \quad \text { perilaku }\end{array}$} \\
\hline
\end{tabular}

\section{Lembar kerja}

Berdasarkan tabel perbandingan pikiran, perasaan dan perilaku sebelum maupun sesudah terapi, dapat disimpulkan bahwa terdapat perubahan positif dalam penilaian AG untuk beberapa situasi. Sebelum pelaksanaan terapi telihat bahwa pemikiran AG cenderung negatif terhadap 
situasi yang diberikan sehingga ikut mempengaruhi emosinya menjadi negatif pula. Sementara itu setelah pelaksanaan terapi, umumnya pemikiran AG lebih positif dan terlihat lebih rasional. Hal ini menunjukkan bahwa adanya perubahan cara pandang (core belief) AG dalam menilai sesuatu. Lebih jelasnya, Tabel 6 menggmbar lembar kerja 2 untuk hasil sebelum dan setelah pelaksanaan terapi sehingga dapat dilihat perbandingannya.

\section{DISKUSI}

Pada kasus AG, seorang anak perempuan berusia 12 tahun yang mengalami masalah emosi yakni memendam keinginan balas dendam terhadap orang yang telah membunuh ayahnya. Sebagai seorang anak yang pernah merasa, mendengar dan melihat situasi konflik selama bertahun-tahun, terlebih kehilangan seorang ayah yang sangat dicintainya, maka timbullah masalah emosi. Hal ini sejalan dengan yang dikatakan oleh Levine dan Kline (2007) bahwa peristiwa yang menyakitkan untuk anak-anak, seperti kematian orang tua dapat menyebabkan trauma yang mendalam hingga mengakibatkan masalah emosi.

Masalah emosi seperti yang dialami AG perlu mendapat penanganan yang tepat agar ia dapat mengontrol emosi yang dirasakannya. Berkaitan dengan hal tersebut diatas, seorang psikolog Universitas Syiah Kuala Darussalam, Nur Jannah Nitura (dalam ANTARA news, 2006) menyebutkan bahwa anak-anak korban konflik yang tersebar di beberapa wilayah rawan gangguan keamanan di Provinsi Nanggroe Aceh (NAD) perlu mendapat penanganan melalui pendekatan psikologis, sebagai upaya menghapuskan rasa dendam dalam diri mereka.

Untuk itu, penanganan yang dilakukan adalah dengan pendekatan $C B T$ dengan tujuan agar AG dapat meningkatkan kemampuan regulasi emosinya. Dengan harapan, setelah kemampuan regulasi emosinya meningkat maka ia lebih mampu memikirkan bahwa apa yang dipendamnya selama ini merupakan hal negatif sehingga secara otomatis keinginan balas dendamnya dapat menghilang sejalan dengan meningkatnya kemampuan regulasi emosinya.

Dalam hal ini, metode yang digunakan adalah cognitive restructuring methods dengan teknik pencatatan pikiran negatif dan problem solving yang dipadukan dengan metode relaksasi dan teknik yang digunakan adalah relaxation via tension relaxation.Martin dan Pears (2007) menyebutkan bahwa cognitive restructuring methods berguna untuk membantu individu agar dapat mengidentifikasi ide atau kepercayaan irasional, dan menggantinya dengan pernyataan yang realistis tentang dunia. Sementara menurut, Davis, Esbelman dan Mckay, (1995), teknik pernafasan pada relaksasi sangat bermanfaat untuk mengurangi gejala emosi yang dialami individu, di antaranya: marah, sikap bermusuhan, mudah tersinggung, dan dendam. Dalam sesi $C B T$ ini, AG akan dipandu untuk memunculkan perilaku yang diharapkan dan mengajarkan padanya bagaimana menghadapi emosi negatif sehingga dapat menghilangkannya dengan sempurna.

Dari pelaksanaan terapi ini diketahui bahwa kemampuan regulasi emosi AG mengalami peningkatan. Walau ia belum bisa melupakan masalah yang telah mengakibatkan ayahnya terbunuh, namun ia masih ingin berusaha belajar memaafkan orang yang telah membunuh ayahnya. Namun dalam penelitian ini tidak dapat dipastikan, apakah teknik problem solving dan pencatatan pikiran negatif untuk digunakan dalam cognitive restructuring methods atau teknik relaksasi yang lebih dominan dalam mempengaruhi perubahan kemampuan regulasi emosi serta kemampuannya dalam mencari jalan keluar dari masalah emosi yang sedang dialaminya. Hal ini dikarenakan teknik di atas merupakan satu kesatuan maka dapat 
dikatakan bahwa terapi yang dilaksanakan dapat meningkatkan kemampuan regulasi emosi pada anak korban konflik Aceh yang mengalami masalah emosi.

Setelah terapi diberikan, kemampuan kendali diri, sikap hati-hati, toleransi terhadap frustasi, memiliki pandangan yang positif terhadap diri sendiri dan lingkungan, lebih dapat melakukan introspeksi diri dan relaksasi serta lebih sering merasakan emosi yang positif dari pada emosi negatif mengalami peningkatan. Sementara itu, kemampuannya dalam menjalin hubungan interpersonal dengan orang lain, adaptabilitas, kepekaan terhadap orang lain dan tidak mudah putus asa tidak mengalami perubahan (menetap). Dengan demikian secara keseluruhan dapat dikatakan bahwa setelah pelaksanaan terapi, kemampuan regulasi emosi AG meningkat. Walau AG belum bisa melupakan masalah yang telah membuat ayahnya meninggal, namun ia mau berusaha belajar memaafkan orang yang telah membunuh ayahnya meskipun dikatakannya tidak mudah baginya untuk memaafkan orang yang telah membunuh ayahnya.

Distorsi kognisi yang muncul/ ditunjukkan pada subjek ini adalah over generalization. Ia menganggap semua tentara harus bertanggung jawab atas kehidupan mereka sebab merekalah yang telah menghilangkan nyawa ayahnya. Setelah terapi, ia menyadari bahwa harus berupaya memaafkan orang yang telah membunuh ayahnya. Hal ini didukung oleh fakta yang ada bahwa ayahnya telah meninggal 8 tahun silam, ia tidak tahu persis siapa yang telah membunuh ayahnya dan kematian ayahnya merupakan takdir dari Allah SWT.

Secara umum pelakasanaan terapi ini berjalan dengan lancar, dimana $A G$ dapat mengikuti proses terapi yang diberikan dengan baik. Terlihat adanya kemauannya untuk untuk terus mengikuti semua sesi terapi sampai akhir. Ia juga mau mengikuti semua instruksi disetiap sesi, mau mengisi lembar kerja yang diberikan meski membutuhkan dorongan serta adanya upaya untuk belajar memaafkan. Namun dalam penerapan $C B T$ pada penelitian ini, menunjukkan beberapa kekurangan yang terjadi selama penelitian ini baik dalam masa terapi maupun selama pelaksanaan penelitian.

Selama pelaksanaan terapi, peneliti berupaya mencari ruangan yang kondusif yakni memilih rumah ibu AL yang biasanya selalu sunyi sehingga lebih tenang. Namun selama pelaksanaan terapi berlangsung terjadi suatu hal diluar dugaan, beberapa kali rumah ibu $\mathrm{AL}$ kedatangan tamu sehingga membuat konsentrasi AG terpecah. Selain itu, kualitas terapis dan waktu pelaksanaan terapi juga merupakan salah satu kekurangan dalam penelitian ini. Terapis menunjukkan kekakuan dalam menjalankan intervensi $C B T$, hal ini disebabkan kurangnya pengalaman dari terapis karena baru pertama sekali melaksanakan terapi ini. Sementara itu mengenai waktu pelaksanaan terapi yang terlalu singkat, hal ini dikarenakan keterbatasan waktu dari partisipan sendiri maka penelitian ini tidak berjalan sesuai dengan waktu terapi yang telah ditentukan sebelumnya. Oleh karena itu, penggunaan waktu dalam terapi perlu diperhatikan untuk penelitian selanjutnya. Senada dengan hal tersebut, oemarjoedi (2003) menyatakan bahwa dalam pelaksanaan $C B T$ dibutuhkan keahlian praktis dan psikologis spesifik seperti refleksi dan evaluasi kembali makna perubahan perilaku dan secara aktif mempromosikan perubahan-perubahan individu.

\section{Kesimpulan}

Dalam penelitian ini tidak dapat dipastikan, apakah teknik problem solving dan pencatatan pikiran negatif untuk digunakan dalam cognitive restructuring methods atau teknik relaksasi yang lebih dominan dalam mempengaruhi perubahan kemampuan regulasi emosi serta kemampuannya dalam mencari jalan 
keluar dari masalah emosi yang sedang dialaminya. Hal ini dikarenakan teknik di atas merupakan satu kesatuan maka dapat dikatakan bahwa terapi yang dilaksanakan dapat meningkatkan kemampuan regulasi emosi pada anak korban konflik Aceh yang mengalami masalah emosi.

Secara keseluruhan intervensi $C B T$ dengan cognitive restructuring methods dan teknik relaksasi dapat meningkatkan kemampuan regulasi emosi subjek penelitian. Hasil yang diperoleh menunjukkan adanya peningkatan kemampuan regulasi emosi subjek penelitian. Setelah terapi diberikan, kemampuan kendali diri, sikap hati-hati, toleransi terhadap frustasi, memiliki pandangan yang positif terhadap diri sendiri dan lingkungan, lebih dapat melakukan introspeksi diri dan relaksasi serta lebih sering merasakan emosi yang positif dari pada emosi negatif mengalami peningkatan. Sementara itu, kemampuannya dalam menjalin hubungan interpersonal dengan orang lain, adaptabilitas, kepekaan terhadap orang lain dan tidak mudah putus asa tidak mengalami perubahan (menetap).

Hal lainnya yang mengalami perubahan adalah kemampuannya dalam menilai suatu situasi sosial. Pada awalnya, AG memiliki distorsi pikiran yang berlebihan (overgeneralization). Ia mempunyai anggapan bahwa tentara harus bertanggung jawab terhadap kehidupan keluarganya, namun setelah terapi diberikan ia memaafkan orang yang telah membunuh ayahnya dan beranggapan bahwa kematian ayahnya merupakan takdir dari Allah SWT.

\section{Saran}

\section{Saran Teoritis}

Peneliti menyadari bahwa banyak hal yang bisa dikembangkan dalam penelitian ini. Untuk itu diharapkan bagi peneliti lain yang ingin meneliti hal yang sama agar memperhatikan hal-hal berikut:
1) Berkaitan dengan pelaksanaan terapi sebaiknya menggunakan cara yang lebih menarik dan kreatif dalam menyampaikan materi misalnya melalui permainan, cerita, dan boneka. Disamping itu, tempat pelaksanaan terapi sebaiknya dilakukan dalam lingkungan yang kondusif dan tenang sehingga konsentrasi anak menjadi tidak terganggu dan dapat mengikuti proses terapi dengan baik serta memperpanjang sesi terapi agar kemampuan regulasi emosi yang dimilikinya dapat dimanfaatkannya untuk menghilangkan keinginan balas dendamnya dengan bantuan terapis.

2) Berkaitan dengan efektifitas terapis, bahwa salah satu faktor pendukung keberhasilan terapi adalah terletak pada terapis yang memiliki kompeten. Dalam hal ini terapis dapat memperkaya keahlian yang dimilikinya, mislanya dengan mengikuti pelatihan yang mendalam mengenai cognitive behavioral therapy sebagai penambah kekayaan ilmu yang dapat diterapkan. Hal ini berguna untuk membiasakan diri terhadap pelaksanaan $C B T$ yang akan diberikan.

\section{Saran Praktis}

Berdasarkan hasil penelitian ini, ada beberapa saran praktis untuk individu yang mengalami masalah emosi dan orang/ lingkungan sekitar anak.

1) Individu yang mengalami masalah emosi, diharapkan dapat selalu melatih kontrol emosi/ regulasi emosi dan mengembangkan pemikiran positif serta terus berupaya agar belajar memaafkan orang yang telah membunuh ayahnya.

2) Lingkungan sekitar, dalam hal ini orang tua membantu anak dalam mengelola emosinya dan membantu memberikan pemahaman dampak negatif dari keinginannya memendam balas dendam. Hal ini disebabkan karena lingkungan menjadi model bagi anak seperti memaafkan orang yang telah membunuh ayahnya. Disamping itu, orang tua juga hendaknya memiliki 
kondisi emosional yang menenangkan, sehingga anak dapat meniru orang tua dalam mengekspresikan emosinya atau menjadi role model bagi anaknya.

\section{REFERENSI}

Antara news.(2006, Agustus 11). Anak Korban Konflik Aceh Perlu Penanganan Khusus. Diambil dari http://www.antaranews.com/view/?i=1 $155261439 \& c=N A S \& s=$.

Atkinson, R. C., dan Hilgard, E. R. (2003). Introduction to Psychology (14th ed). USA: Thomson Wadsworth.

American Psychiatric Association. (2000). Diagnostic and Statistical Manual of Mental Disorders (4th ed. Text Revision). Washington, DC: APA

Davis, M., Esbelman, E. R., dan Mckay, M. (1995). Panduan Relaksasi dan Reduksi Stres-edisi 3. Jakarta: Penerbit Buku Kedokteran EGC.

Goleman, D. (2009). Emotional intelligence: mengapa EI lebih penting daripada IQ. Jakarta: PT. Gramedia Pustakan Utama.

Grunady.(2007). Mengunggkap Kekerasan Aceh. Lhokseumawe: Seuramoe Press.

Kelompok Kerja Gender.(2007). Evaluasi Situasi Perempuan Tahun 2006 Di Aceh. Aceh: LSM Gender Working Group.

Levine, P.A., dan Kline. M. (2007).Trauma through a Child's EyesAwakening the Ordinary Miracle of Healing-Infancy through Adolescence. California: North Atlantic Books.

Lumongga, N. (2009). Depresi-Tinjauan Psikologis. Jakarta: Kencana Prenada Media Group.

Martin, A. D. (2003). Emotional quality management. Jakarta: Arga.

Martin, G., dan Pears, J. (2007). Behavior Modification: what it is and how to do it (seventh edition). New Jersey: Prentice Hall
Muzakkar, Q., dan Alwie, T. (2009). Pesantren Korban Konflik Aceh Agar Dendam Tidak Lagi Membara. Majalah Gatra Nomor 1 Beredar Kamis, 12 November 2009.

Oemarjoedi, A. K. (2003). Pendekatan Cognitive Behavior dalam Psikoterapi. Jakarta: Penerbit Creativ Media.

Rusmana, N, dkk. (2006). Efektifitas Play Therapy Terhadap anak-anak yang Mengalami PTSD-Tesis.Universitas Pendidikan Indonesia.

Safaria, T., dan Saputra, N. E. (2009). Manajemen Emosi, Sebuah Panduan Cerdas Bagaimana Mengelola Emosi Positif dalam Hidup Anda-edisi 1. Jakarta: Bumi Aksara.

Schiraldi, G. (2009). The Post Traumatic Stress Disorder Sourcebook-A guide to Healing Recovery and Growth (second edition). New York: Mc. Graw Hill.

Stallard, P. (2005). A Clinician's Guide to think Good-Feel Good (using CBT with children and young people). England: John Wiley\&sons Ltd.

Setyawan, I. (2007). Membangun Pemaafan Pada Anak Korban Perceraian. Makalah ini dipresentasikan pada Konferensi Nasional I IPK-HIMPSI: Stress Management dalam Berbagai Setting Kehidupan, Bandung 2-3 Februari 2007. Semarang: Program Studi Psikologi Universitas Diponegoro. 